NAME

profile

DATE AND NAME OF TESTS

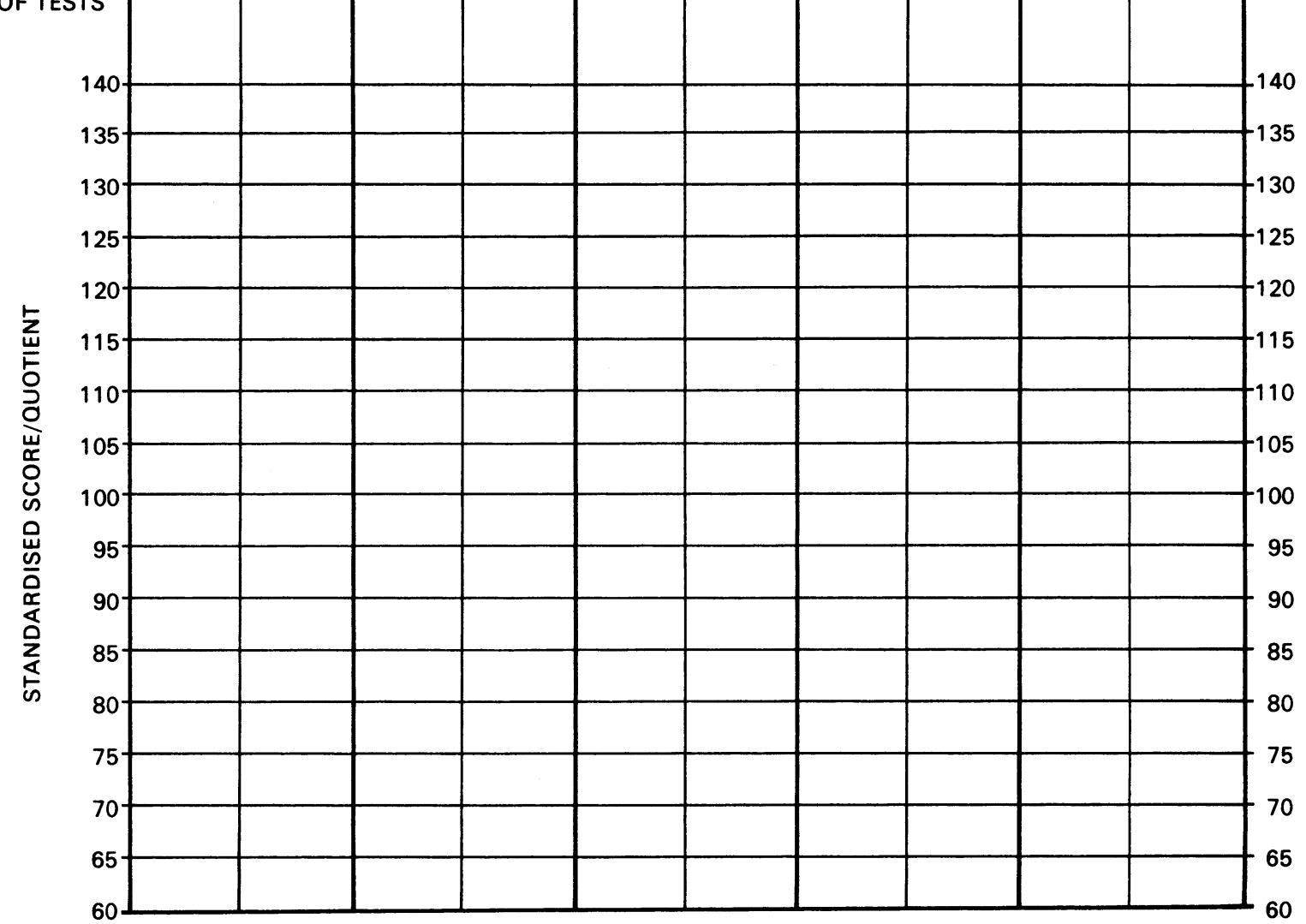

Teacher's remarks

\title{
Formula
}

(Reading/Maths etc.) Quotient

Reading/Maths etc. age $=\frac{\text { Chronological age }}{\text { Con }} \times 100$

\section{Colour key}

Blue: Reading score

Red: Maths score

Green:

Black:

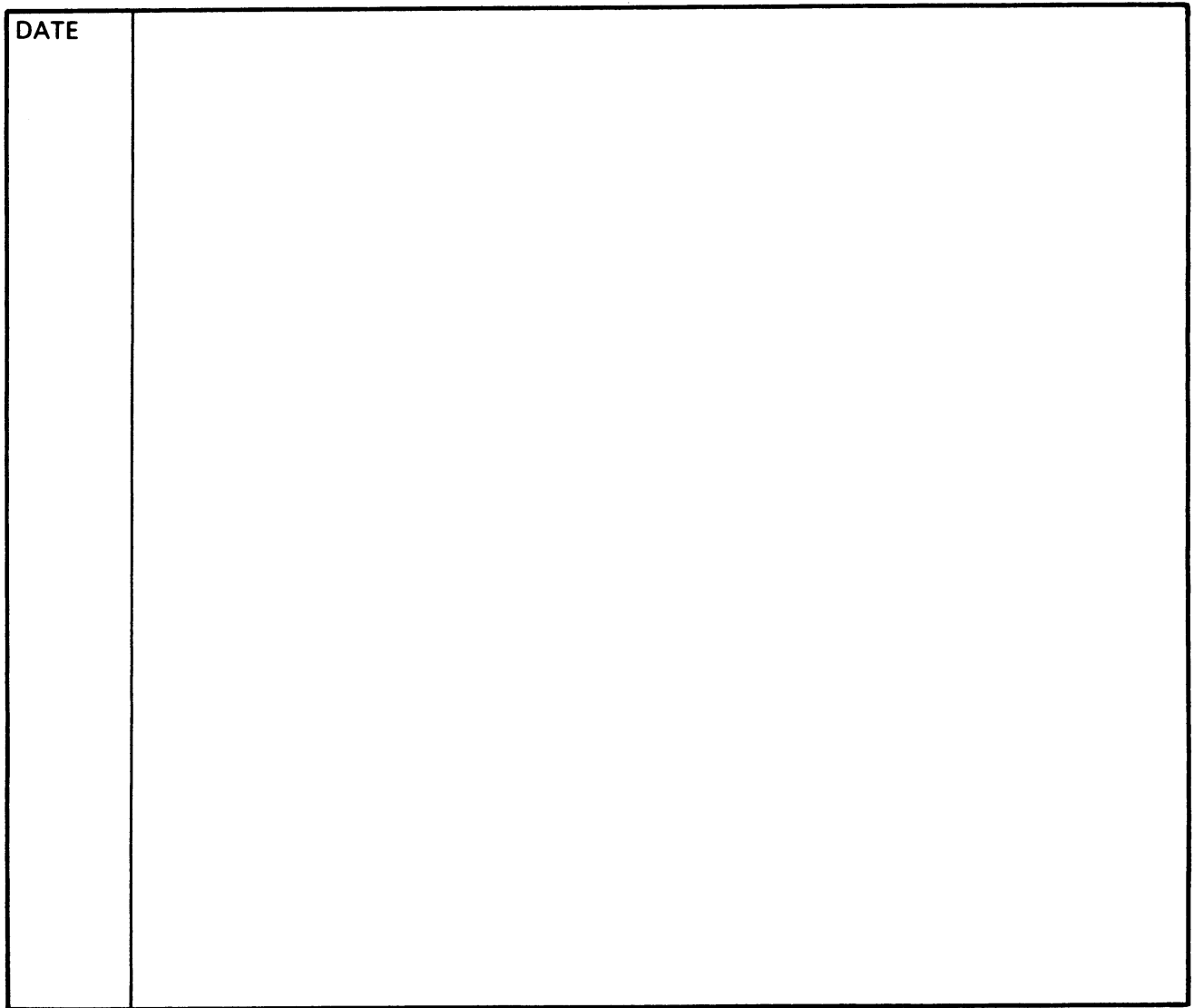

(C) 1982 Peter Birks Published by Macmillan Education Ltd, London and Basingstoke Printed in Great Britain 
ISBN 978-1-349-16691-6

ISBN 978-1-349-16689-3 (eBook)

DOI 10.1007/978-1-349-16689-3 